Review

\title{
Epidural Steroid Injections for Low Back Pain: A Narrative Review
}

\author{
Massimiliano Carassiti ${ }^{1, *}$, Giuseppe Pascarella ${ }^{1}$, Alessandro Strumia ${ }^{1}$, Fabrizio Russo ${ }^{2}$, \\ Giuseppe Francesco Papalia ${ }^{2}{ }^{-}$, Rita Cataldo ${ }^{1}$, Francesca Gargano ${ }^{1}$, Fabio Costa ${ }^{1}$, Michelangelo Pierri ${ }^{3}$,

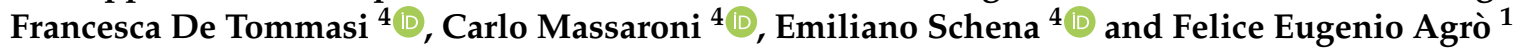 \\ 1 Unit of Anaesthesia, Intensive Care and Pain Management, Department of Medicine, \\ Campus Bio-Medico University of Rome, 00128 Rome, Italy; g.pascarella@unicampus.it (G.P.); \\ a.strumia@unicampus.it (A.S.); r.cataldo@unicampus.it (R.C.); f.gargano@unicampus.it (F.G.); \\ f.costa@unicampus.it (F.C.); f.agro@unicampus.it (F.E.A.) \\ 2 Department of Orthopaedic and Trauma Surgery, Campus Bio-Medico University of Rome, 00128 Rome, Italy \\ fabrizio.russo@unicampus.it (F.R.); g.papalia@unicampus.it (G.F.P.) \\ 3 Integrated Sleep Surgery Team UCBM, Unit of Otolaryngology, Integrated Therapies in Otolaryngology, \\ Campus Bio-Medico University of Rome, 00128 Rome, Italy; michelangelo.pierri@unicampus.it \\ 4 Unit of Measurements and Biomedical Instrumentation, Department of Engineering, \\ Campus Bio-Medico University of Rome, 00128 Rome, Italy; f.detommasi@unicampus.it (F.D.T.); \\ c.massaroni@unicampus.it (C.M.); e.schena@unicampus.it (E.S.) \\ * Correspondence: m.carassiti@unicampus.it
}

\section{check for}

updates

Citation: Carassiti, M.; Pascarella, G.; Strumia, A.; Russo, F.; Papalia, G.F.; Cataldo, R.; Gargano, F.; Costa, F.; Pierri, M.; De Tommasi, F.; et al. Epidural Steroid Injections for Low Back Pain: A Narrative Review. Int. J. Environ. Res. Public Health 2022, 19, 231. https://doi.org/10.3390/ ijerph19010231

Academic Editor: Paul B.

Tchounwou

Received: 3 December 2021

Accepted: 22 December 2021

Published: 26 December 2021

Publisher's Note: MDPI stays neutral with regard to jurisdictional claims in published maps and institutional affiliations.

Copyright: (C) 2021 by the authors. Licensee MDPI, Basel, Switzerland. This article is an open access article distributed under the terms and conditions of the Creative Commons Attribution (CC BY) license (https:// creativecommons.org/licenses/by/ $4.0 /)$.

\begin{abstract}
Low back pain represents a significant socioeconomic burden. Several nonsurgical medical treatments have been proposed for the treatment of this disabling condition. Epidural steroid injections (ESIs) are commonly used to treat lumbosacral radicular pain and to avoid surgery. Even though it is still not clear which type of conservative intervention is superior, several studies have proved that ESIs are able to increase patients' quality of life, relieve lumbosacral radicular pain and finally, reduce or delay more invasive interventions, such as spinal surgery. The aim of this narrative review is to analyze the mechanism of action of ESIs in patients affected by low back pain and investigate their current application in treating this widespread pathology.
\end{abstract}

Keywords: epidural steroid injections; low back pain; lumbosacral radicular pain; disk herniation; canal stenosis; review

\section{Introduction}

Low back pain (LBP) and lumbosacral radicular pain are common causes of physical and mental morbidity and they are also a significant economic burden, causing an expenditure of more than USD 100 billion per year in the United States alone [1,2]. In the medical literature, low back pain is referred to as sciatica, lumbosacral radicular syndrome, lumbar radiculopathy, nerve root pain and nerve root entrapment/irritation, and is commonly described as a pain starting in the back and radiating to the legs. The etiological cause of low back pain is first represented by intervertebral disk disease. The pathophysiological changes involved in the intervertebral disk disease may lead to disk herniation or degenerative diseases, such as canal stenosis or chronic instability of the diseased segments. The most common cause of sciatica is the herniation of the nucleus pulposus, a component of the intervertebral disk in the lumbar region, which causes stenosis and inflammation [3,4]. Some estimate that sciatica caused by herniation of the lumbar disk has a prevalence of 9.8 out of 1000 [5], meaning that of all reported cases of sciatica it appears that $90 \%$ are caused by herniation of the lumbar disk [6].

Several nonsurgical medical treatments have been proposed for lumbosacral radicular pain, from lifestyle changes, exercise and physical therapy to analgesic local/oral drugs and epidural steroid injections (ESIs) $[7,8]$. The conservative management of LBP aims to delay or avoid surgery. As a matter of fact, LBP can improve spontaneously or with 
conservative treatment. Cases which do not respond to treatment are candidates for surgical intervention.

An ESI is a common and minimally invasive procedure, performed to successfully treat lumbosacral radicular pain, which has also proved its effectiveness in the treatment of back acute pain and leg symptoms. The injections are used to deliver steroids, and sometimes local anesthetics, to the epidural space, directly to the site that causes the pain using a caudal, interlaminar or transforaminal approach [9]. The epidural injection is a well-founded anesthetic and analgesic technique; moreover, nowadays, new technological devices can help anesthesiologists to learn and to administer it [10-16]. Even though it is still not clear which type of conservative intervention is superior, several studies have proved that an ESI is able to increase patients' quality of life, relieve lumbosacral radicular pain and finally, reduce or delay more invasive interventions, such as spinal surgery. Although ESIs should represent a treatment of choice in the case of acute LBP or leg pain, in our research we focused on the efficacy of ESIs in the treatment of chronic LBP.

The aim of this narrative review is to analyze the mechanism of action of ESIs in chronic lumbar pain patients and to understand their current use, application and success in treating this significant widespread pathology.

\section{Materials and Methods}

A literature review using online databases was carried out regarding the use of epidural steroid injections for lumbar canal stenosis and disk herniation. Articles were extracted from PubMed, Google Scholar, MEDLINE, UpToDate, Embase and Web of Science, combining the terms "spinal disease," "radicular pain," "spinal stenosis," "canal stenosis," "disk herniation" and "epidural steroid injection" as keywords for the research. Only papers in the English language and regarding human studies were taken into consideration. Non-English language studies were excluded. Scientific publications up to September 2021were included. Only papers focusing on epidural steroid injections for lumbar canal stenosis or disk herniation were included. All reference lists of the relevant studies were then screened to identify any missing publications. The search and the study selection were performed by two investigators (G.P.; A.S.) working independently. At the first level, the titles and abstracts of identified studies were screened. At the second level, the full texts were retrieved and assessed. Ethical approval and patient informed consent were not required because this was a review of previously published studies and did not involve direct contact with patients or alterations to patient care. Any discrepancies were resolved by a third author (M.C.) through consensus. The following data were extracted from each eligible study: first author's name; publication year; study design; intervention protocol type (the type and amount of steroid and local anesthetic used for the ESI and therapies or medication used for conservative treatment); outcome parameters including Visual Analogic Scale (VAS), Numeric Rating Scale (NRS), Oswestry Disability Index (ODI) and successful events; and the summary of findings.

\section{Results}

\subsection{Mechanism of Lumbosacral Radicular Pain}

Low back pain and radicular pain are caused by interrelated biomechanical and biochemical factors. With the advancement of age and the presence of chronic diseases such as diabetes, obesity, smoking and overload, a series of degenerative processes occur inside the intervertebral disk [17]. The intervertebral disk is approximately 7 to $10 \mathrm{~mm}$ thick and $4 \mathrm{~cm}$ in diameter and is formed of two different components: the nucleus pulposus, rich in water and glycopeptides, and the anulus fibrosus, constituted of a series of 15 to 25 rings, or lamellae, with collagen fibers parallel to the lamellae in addition to elastin fibers. A thin hyaline cartilage endplate is the interface between the disk and the superior and inferior vertebrae bodies. When the nucleus becomes less elastic and the anulus less continent due to aging, dehydration, inflammatory conditions and/or prolonged misusage of the back, a part of the nucleus can herniate, usually backward. This causes an inflammatory 
state in the epidural space and the increase in cytokines and other inflammation mediators. This condition, on the one hand favors the ulterior herniation of the nucleus pulposus and on the other, it compresses and stimulates the spinal nerve roots, resulting in back and radicular pain $[18,19]$.

Generally, sciatica from lumbar disk herniation is a self-limiting condition that improves in weeks or months without medical intervention; in some cases, rest, analgesic drugs and a structured exercise program may be needed. Usually, the inflammatory state is more important than the mechanical compression in the pathogenesis and the chronicity of the disease, unless there are no neurological deficits [20]. However, in patients who are refractory to conservative treatment, surgery is usually recommended.

Lumbar spinal canal stenosis is a process that could be part of the aging process and can be related to herniation of an intervertebral disk. Other common causes of stenosis are: congenital deformities; spondylolisthesis; osteophytes; arthritic degeneration; synovial cysts; hypertrophy of the facet joints; hypertrophy of the ligamentum flavum; epidural lipomatosis; spondylosis of the intervertebral disk margins; previous surgery; and neoplastic diseases. All these factors could cause lumbar nerve root compression with microvascular ischemia, axonal injury, intraneural fibrosis and an inflammatory state, leading to chronic back pain [21].

\subsection{Rationale of Epidural Steroid Injections}

Epidural injections are performed using a Tuohy needle with the tip placed inside the epidural space, which is located between the ligamentum flavum and the dura mater. Usually, the epidural space is localized thanks to the loss of resistance (LOR) technique, where the needle is advanced between the spinal processes of the vertebras with the help of a syringe full of air or saline solution, which is used to continuously test the pressure on the piston of the syringe. The needle passes through the ligamentum flavum and, when the epidural space is reached, a loss of resistance is felt by the operator on the syringe piston. Moreover, epidural injections can also be performed rapidly under CT and navigation guidance (Figure 1). These techniques can be used to precisely guide needle placement, allowing for the visualization of the optimal needle path and identification of potential problems, such as narrow intralaminar spaces and spinal stenosis, before needle insertion (Figure 2).

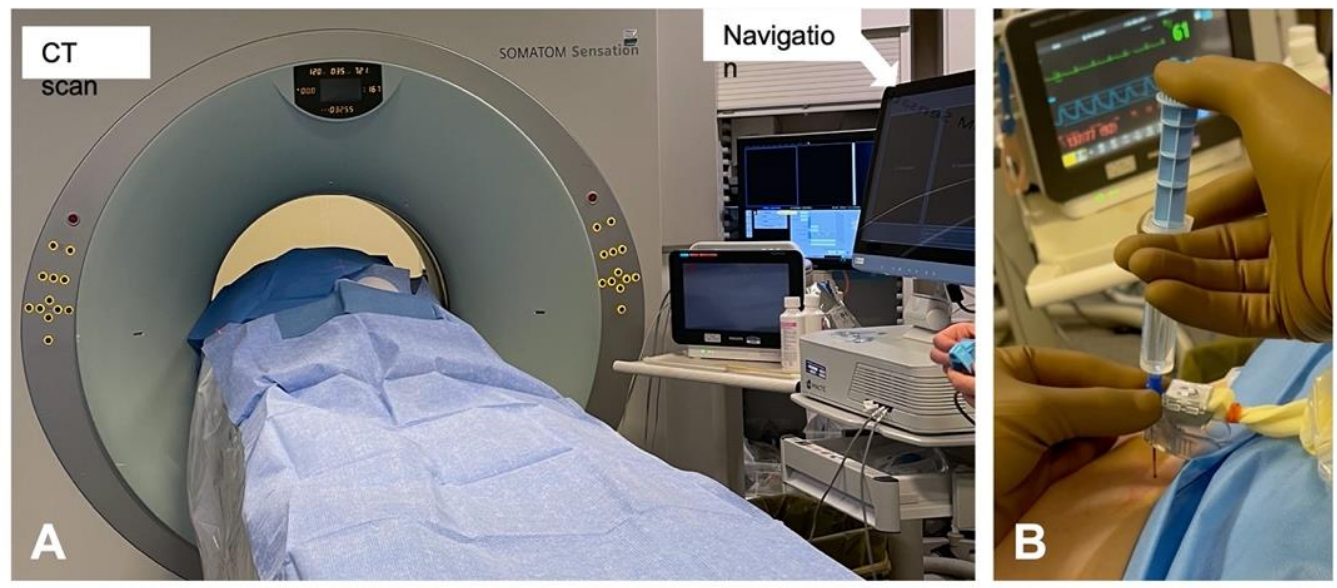

Figure 1. Representative images of (A) intraoperative setting for $\mathrm{CT}$ and navigation guided epidural injection and (B) navigated needle insertion. 

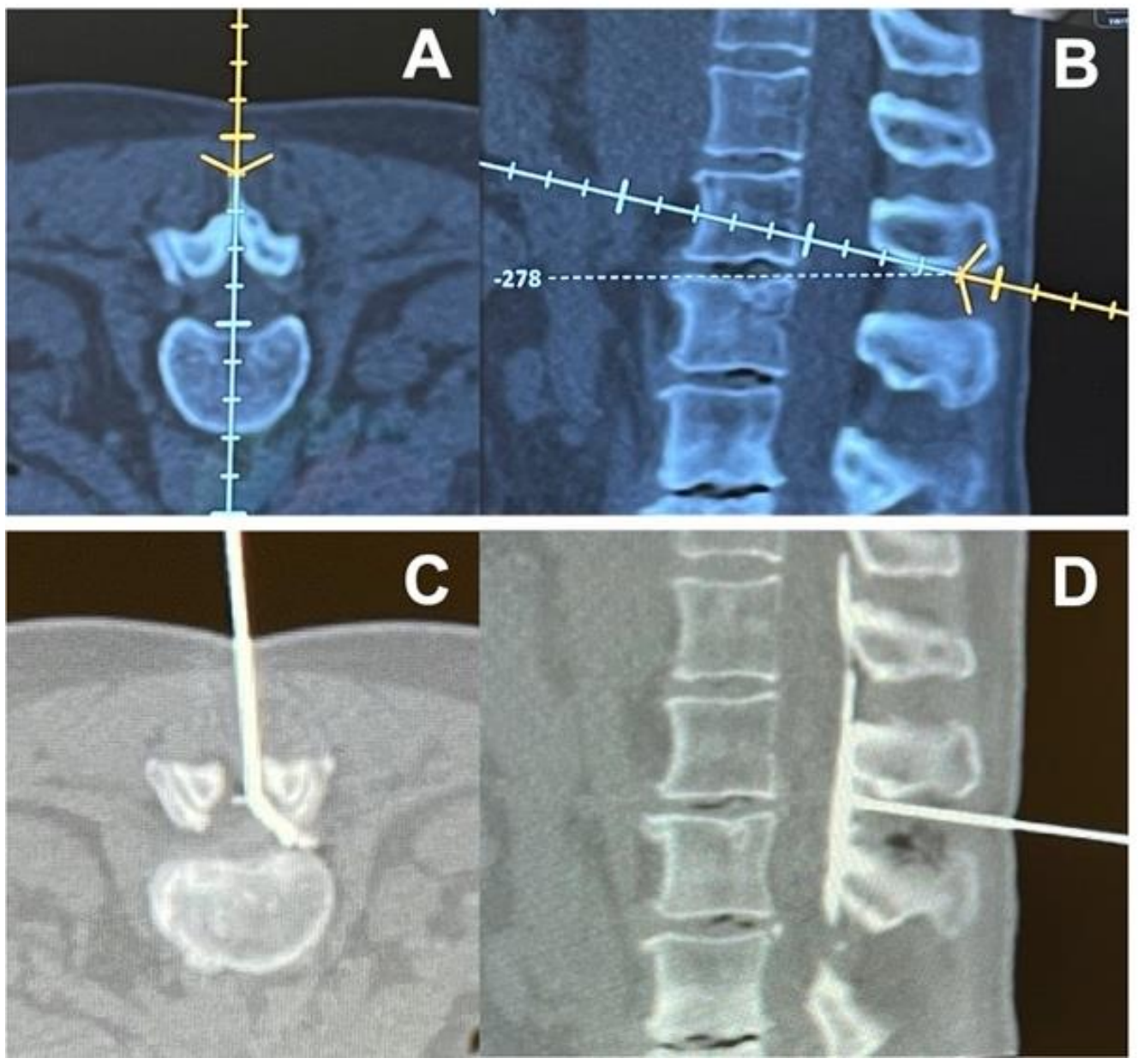

Figure 2. Representative images of $(\mathbf{A}, \mathbf{B})$ navigated planning of needle path to the epidural space and $(\mathbf{C}, \mathbf{D})$ evidence of injection in the epidural space by the use of a contrast agent.

Corticosteroids are widely used in regional anesthesia and chronic pain procedures, such as epidural injections, intraarticular injections and nerve blocks. Corticosteroids have a similar structure and activity to the endogenous produced hormone cortisol, which has an anti-inflammatory, immunosuppressive, vasoconstrictive and antiproliferative effect. They work by preventing the enzyme PLA2 from liberating arachidonic acid from the cells. This inhibits the cyclo-oxygenase and lipoxygenase production, which is responsible for the level of prostaglandins, thromboxanes and leukotrienes, before finally decreasing the inflammatory state [22]. They also inhibit the nerve transmission in nociceptive C fibers and reduce vasal permeability, which decreases intraneural and perineural oedema. Local anesthetics have been administered in the epidural space since 1901; however, the epidural use of corticosteroids has only been documented since 1952 [23]. Their efficacy when administrated via epidural injections has been demonstrated in various studies and a stronger effect has been proven in patients with a higher protein count in the cerebrospinal fluid, which is usually associated with an inflammatory state [24]. The prolonged use of corticosteroids at high doses has many systemic side effects and can also result in iatrogenic adrenal gland suppression; however, the epidural administration limits the systemic side effects because a smaller dose is necessary to reach the pharmacological target and its diffusion into systemic circulation is more difficult than in other types of administration [25]. In the Yang et al. [26] meta-analysis regarding lumbosacral radicular pain due to any cause, the use of ESIs resulted in the more effective in control of lumbosacral pain compared to pure conservative treatment, both in short and intermediate terms. However, two other recent meta-analyses have shown a similarity in efficacy and duration, in terms of pain 
reduction and functional gain, between local anesthetic alone or local anesthetic with a corticosteroid epidural injection $[27,28]$.

\subsection{Epidural Steroid Injections for Disk Herniation Lumbar Pain}

The epidural administration of corticosteroids is one of the most common miniinvasive medical treatments for chronic spinal pain caused by disk herniation [29,30]. In fact, in the absence of chronic severe pain or neurological deficit, epidural steroid injections may be the treatment of choice for disk herniation. As mentioned before, it reduces the concentration of inflammatory mediators in the epidural space and vascular permeability [31]; it also reduces the damage of $C$ fibers, which diminishes the pain [32,33]. In particular, the anesthetic effect of methylprednisolone over other steroids and non-steroid anti-inflammatory drugs has been proven when injected into the epidural space [34].

In clinical practice, both corticosteroids and local anesthetics are used $[35,36]$; the former are used to reduce the inflammation for a prolonged time, while the latter are used to mitigate the discomfort of the procedure and immediately decrease pain.

The difference in the use of a local anesthetic alone or local anesthetic with a corticosteroid in the epidural administration to treat disk herniation pain has been indagated in numerous papers without a clear result $[37,38]$, although a meta-analysis written by Lee at al. evidenced a small difference between the epidural injection of lidocaine and lidocaine plus corticosteroids [39].

However, a good number of studies have described significant pain relief and improvement of functional status after an ESI, especially in short-medium terms [40-45] (Table 1). In fact, Kennedy and colleagues have found a high rate of success of ESIs at 6 months in their study, but there was also a recurrence of the symptoms during the 5 years follow-up after the injection [46]. In a similar way, Buchner et al. found a significant improvement in patients treated with epidural steroid injections for a very short period after the treatment but no improvement was seen after 6 weeks and 6 months, compared to the control group who did not receive the injection [47]. A response to the treatment after $1 \mathrm{~h}$ of having the procedure has been suggested as predictive for favorable medium-term success [48]. Interestingly, Buttermann et al. suggested that ESIs could be more effective in patients who presented magnetic resonance imaging of inflammatory endplate changes [49].

On the other hand, the Spine Patient Outcomes Research Trial (SPORT) [50], a prospective multi-center study of the operative versus nonoperative treatment of lumbar intervertebral disk herniation, found no improvement in short- or long-term outcomes in patients who received ESIs compared to patients who did not. However, it is important to say that an increased rate of surgical avoidance was observed in the group treated with ESIs; this could underline the role of conservative treatments, also considering the high incidence of the spontaneous reabsorption of lumbar disk herniation $(66.66 \%$ according to Zhong et al.) [51].

Finally, Kreiner et al. [52], in their guideline for the diagnosis and treatment of disk herniation with radicular pain, stated that an ESI is indicated for a proportion of patients with lumbar disk herniation to provide symptom relief in the short term (2-4 weeks) with a grade A recommendation. Additionally, at the moment, no sufficient evidence exists to make a recommendation regarding the 12-month, or more, efficacy of ESIs. 
Table 1. Epidural steroid injections for disk herniation studies.

\begin{tabular}{|c|c|c|c|c|c|}
\hline \multirow[t]{2}{*}{ Author, Year } & \multirow[t]{2}{*}{ Study Design } & \multicolumn{2}{|c|}{ Study Protocol } & \multirow[t]{2}{*}{ Outcome Measures } & \multirow[t]{2}{*}{ Summary of Findings } \\
\hline & & Steroid Injection & Control & & \\
\hline $\begin{array}{l}\text { Sariyildiz MA, } \\
\quad 2017[40]\end{array}$ & $\begin{array}{l}\text { Prospective (repeated } \\
\text { measures) }\end{array}$ & $\begin{array}{l}\text { Transforaminal, } 40 \mathrm{mg} \\
\text { betamethasone }+ \\
\text { lidocaine } 2 \%\end{array}$ & Baseline & $\begin{array}{l}\text { VAS, Oswestry Disability Index } \\
\text { (ODI), hospital anxiety and } \\
\text { depression scale, and Pittsburgh } \\
\text { Sleep Quality Index (PSQI) }\end{array}$ & $\begin{array}{l}\text { Compared to baseline measurements, there } \\
\text { were significant improvements }(>50 \%) \text { in } \\
\text { radicular pain, ODI, depressive symptoms } \\
\text { and PSQI scores at two weeks and } \\
12 \text { months after injection }\end{array}$ \\
\hline Guclu B, 2020 [41] & $\begin{array}{l}\text { Prospective (repeated } \\
\text { measures) }\end{array}$ & $\begin{array}{c}\text { Transforaminal } \\
3 \mathrm{~mL} 0.33 \% \text { lidocaine }+ \\
4 \mathrm{mg} \text { dexamethasone }\end{array}$ & Baseline & VAS scores at 12 weeks & $\begin{array}{c}\text { Transforaminal epidural steroid injection is } \\
\text { effective in relieving radicular pain, } \\
\text { especially in paramedian lumbar } \\
\text { disk herniation }\end{array}$ \\
\hline $\begin{array}{l}\text { Kennedy DJ, } \\
2017 \text { [46] }\end{array}$ & Prospective & $\begin{array}{l}\text { Transforaminal epidural } \\
\text { steroid injection }\end{array}$ & Baseline & $\begin{array}{l}\text { Presence of recurrent or persistent } \\
\text { pain, pain within the previous week, } \\
\text { current opioid use for radicular } \\
\text { symptoms, need for additional spinal } \\
\text { injections, progression to surgery } \\
\text { and unemployment due to pain }\end{array}$ & $\begin{array}{l}\text { Despite a high success rate at } 6 \text { months, the } \\
\text { majority of subjects experienced a } \\
\text { recurrence of symptoms at some time } \\
\text { during the subsequent } 5 \text { years. Few reported } \\
\text { current symptoms and a small minority } \\
\text { required additional injections, surgery or } \\
\text { opioid pain medications }\end{array}$ \\
\hline $\begin{array}{l}\text { Manchikanti L, } \\
2014[30]\end{array}$ & RCT, double-blind & $\begin{array}{l}\text { Interlaminar } 0.5 \% \text { lidocaine } \\
(6 \mathrm{~mL})+1 \mathrm{~mL} \\
\text { betamethasone }\end{array}$ & $0.5 \%$ lidocaine $(6 \mathrm{~mL})$ & $\begin{array}{l}\text { Numeric Rating Scale (NRS), } \\
\text { Oswestry Disability Index 2.0 (ODI), } \\
\text { opioid intake }\end{array}$ & $\begin{array}{l}\text { Improvement in } 70 \% \text { of the steroid group } \\
\text { and } 60 \% \text { of the control group at the end of } \\
2 \text { years. }\end{array}$ \\
\hline $\begin{array}{l}\text { Manchikanti L, } \\
2013 \text { [31] }\end{array}$ & RCT, double-blind & $\begin{array}{c}\text { Interlaminar } 0.5 \% \text { lidocaine } \\
(5 \mathrm{~mL})+1 \mathrm{~mL} \\
\text { betamethasone }\end{array}$ & $0.5 \%$ lidocaine $(6 \mathrm{~mL})$ & $\begin{array}{l}\text { Pain relief and functional status } \\
\text { improvement of } \geq 50 \%\end{array}$ & $\begin{array}{l}\text { Average relief of } 33.7 \pm 18.1 \text { weeks in the } \\
\text { local anesthetic group and } 39.1 \pm 12.2 \text { weeks } \\
\text { in the local anesthetic and steroid group }\end{array}$ \\
\hline $\begin{array}{l}\text { Buchner M, } \\
2000[47]\end{array}$ & $\mathrm{RCT}$ & $\begin{array}{l}\text { Interforaminal } 100 \mathrm{mg} \\
\text { methylprednisolone in } \\
10 \mathrm{~mL} \text { bupivacaine } 0.25 \%\end{array}$ & $\begin{array}{c}10 \mathrm{~mL} \\
\text { bupivacaine } 0.25 \%\end{array}$ & $\begin{array}{l}\text { VAS, straight leg raising test and } \\
\text { functional status }\end{array}$ & $\begin{array}{l}\text { No significance on pain relief, improvement } \\
\text { of straight leg raising and improvement of } \\
\text { functional status at } 6 \text { weeks and } 6 \text { months }\end{array}$ \\
\hline
\end{tabular}


Table 1. Cont.

\begin{tabular}{|c|c|c|c|c|c|}
\hline \multirow[t]{2}{*}{ Author, Year } & \multirow[t]{2}{*}{ Study Design } & \multicolumn{2}{|c|}{ Study Protocol } & \multirow[t]{2}{*}{ Outcome Measures } & \multirow[t]{2}{*}{ Summary of Findings } \\
\hline & & Steroid Injection & Control & & \\
\hline Vad VB, 2002 [44] & RCT & $\begin{array}{l}\text { Transforaminal epidural } \\
\text { steroid injection }\end{array}$ & $\begin{array}{l}\text { Saline trigger-point } \\
\text { injection }\end{array}$ & $\begin{array}{l}\text { VAS, patient satisfaction scale, } \\
\text { Roland-Morris low back } \\
\text { pain questionnaire }\end{array}$ & $\begin{array}{l}\text { At } 1.4 \text { years, the group receiving } \\
\text { transforaminal epidural steroid injections } \\
\text { had a success rate of } 84 \% \text {, vs. } 48 \% \text { for the } \\
\text { control group }\end{array}$ \\
\hline $\begin{array}{l}\text { Butterman GR, } \\
\text { 2004 [49] }\end{array}$ & Prospective & Epidural steroid injection & Baseline & $\begin{array}{l}\text { VAS, Oswestry Disability Index } \\
\text { [ODI], pain diagram }\end{array}$ & $\begin{array}{l}\text { At } 2 \text { years, it was beneficial for a small } \\
\text { number of patients with advanced disk } \\
\text { degeneration and chronic low back pain. It } \\
\text { was more effective in } \\
\text { discogenic inflammation }\end{array}$ \\
\hline $\begin{array}{l}\text { Manchikanti L, } \\
\quad 2008[45]\end{array}$ & $\mathrm{RCT}$ & $\begin{array}{l}\text { Caudal epidural injections } \\
\text { with } 9 \mathrm{~mL} 0.5 \% \text { lidocaine } \\
\text { mixed with } 1 \mathrm{~mL} \text { steroid } \\
\text { (6 mg betamethasone or } \\
40 \mathrm{mg} \text { methylprednisolone) }\end{array}$ & $\begin{array}{l}\text { Caudal epidural } \\
\text { injections with } 0.5 \% \\
\text { lidocaine } 9 \mathrm{~mL}\end{array}$ & NRS, ODI, opiod intake & $\begin{array}{l}\text { Comparable efficacy in both groups at } \\
\qquad 12 \text { months }\end{array}$ \\
\hline $\begin{array}{l}\text { Radcliff K, } \\
2012[50]\end{array}$ & Prospective & Epidural steroid injection & $\begin{array}{l}\text { No epidural } \\
\text { steroid injection }\end{array}$ & VAS, ODI, patient satisfaction & $\begin{array}{l}\text { No improvement in short- or long-term } \\
\text { outcomes ( } 4 \text { years) compared to patients } \\
\text { who were not treated with ESIs }\end{array}$ \\
\hline Şencan S, 2020 [48] & Retrospective & $\begin{array}{l}\text { Transforaminal epidural } \\
\text { steroid injection }\end{array}$ & Baseline & NRS & $\begin{array}{l}\text { A decreased pain scores at } 1 \mathrm{~h} \text { is a predictor } \\
\text { for a favorable 3-month response to an ESI }\end{array}$ \\
\hline
\end{tabular}

LDH = lumbar disk herniation; VAS = visual analogue scale; FU = follow-up; ESI = epidural steroid injections. 


\subsection{Epidural Steroid Injections for Canal Stenosis Lumbar Pain}

The administration of steroids via epidural injection as a nonsurgical treatment for lumbar spinal stenosis (LSS) has been analyzed in various studies but, again, there is not a clear consensus regarding their efficacy in relieving the symptoms, especially in the long-term follow-ups. It is important to notice that a consistent number of studies have reported some degree of benefit, especially regarding short-term improvements [53-59] (Table 2). A more favorable response seems to be associated with relative youth, female sex and patients with single level stenosis, while BMI, MRI severity and the dimension of the spinal canal are probably not predictive $[55,60,61]$. Additionally, individual pain sensitivity does not seem to influence the outcome of an ESI in the patients affected by LSS [62]. Interestingly, Milburn and colleagues, in a randomized study, suggested that the response to the treatment is maximized when the ESI is performed at the intervertebral level of maximal stenosis [63], and their result was confirmed by the trial conducted a few years later by Bajpai et al. [64].

A randomized, double-blind controlled trial with a 2-year follow-up was conducted by Manchikanti et al., which compared the epidural injection of local anesthetic alone to local anesthetic plus steroids, and the authors found a significant relief of the symptoms in a convincing percentage of the patients treated, but without significant difference between the two groups [65]. Accordingly, another large randomized trial on 400 patients, conducted by Friedly and colleagues, found minimal or no short-term benefits in adding steroids to a local anesthetic epidural injection for the treatment of LSS [66].

Moreover, some other studies did not find any significant improvement in symptoms or quality of life after an ESI for the treatment of LSS [67-70]. Tran et al. wrote a review regarding the nonsurgical treatment of LSS and concluded that the literature could provide only limited evidence to formulate recommendations pertaining to the nonsurgical treatment of LSS [71].

Finally, Liu et al., in their systematic review and metanalysis, also concluded that there is minimal evidence to show that epidural steroids are better than local anesthetic alone in the treatment of LSS patients [72]. 
Table 2. Epidural steroid injections for canal stenosis studies.

\begin{tabular}{|c|c|c|c|c|c|}
\hline \multirow[t]{2}{*}{ Authors, Year } & \multirow[t]{2}{*}{ Study Design } & \multicolumn{2}{|c|}{ Study Protocol } & \multirow[t]{2}{*}{ Outcome Measures } & \multirow[t]{2}{*}{ Summary of Findings } \\
\hline & & Intervention & Control & & \\
\hline $\begin{array}{l}\text { Sabbaghan S et al., } \\
2020[53]\end{array}$ & $\begin{array}{l}\text { Retrospective, } \\
\text { single arm }\end{array}$ & $\begin{array}{l}\text { Bupivacaine hydrochloride } \\
0.5 \%(3 \mathrm{~mL})+\text { triamcinolone } \\
\text { acetonide } 80 \mathrm{mg}(2 \mathrm{~mL})\end{array}$ & Baseline & $\begin{array}{l}\text { VAS for lumbar pain, VAS for } \\
\text { lower limb pain and ODI }\end{array}$ & $\begin{array}{l}\text { Improvement in pain (both lumbar } \\
\text { than lower limb) and ability }\end{array}$ \\
\hline $\begin{array}{l}\text { Park CH et al., } \\
\quad 2014[54]\end{array}$ & $\begin{array}{l}\text { Prospective, } \\
\text { single arm }\end{array}$ & $\begin{array}{l}2 \text { mg preservative-free } \\
\text { ropivacaine }+1500 \text { units } \\
\text { hyaluronidase }+40 \mathrm{mg} \\
\text { triamcinolone acetonide }\end{array}$ & Baseline & $\begin{array}{l}\text { 5-point patient satisfaction scale at } \\
2 \text { and } 8 \text { weeks post-treatment }\end{array}$ & $\begin{array}{l}\text { The ESI seems to provide effective } \\
\text { short-term pain relief from LSS. The } \\
\text { grade of LSS appears to have no effect } \\
\text { on the degree of pain relief }\end{array}$ \\
\hline $\begin{array}{l}\text { Cosgrove JL et al., } \\
2011[55]\end{array}$ & $\begin{array}{l}\text { Prospective, } \\
\text { single arm }\end{array}$ & Steroids, not specified & Baseline & $\begin{array}{l}\text { Self-reported activity level and } \\
\text { measured walking ability using the } \\
\text { SSSQ and SMWT. The results were } \\
\text { correlated through demographic } \\
\text { data, magnetic resonance imaging } \\
\text { (MRI) characteristics and } \\
\text { electrodiagnostic results }\end{array}$ & $\begin{array}{c}\text { Significant improvement as measured } \\
\text { by changes in SMWT and SSSQ. } \\
\text { Relative youth and female sex are } \\
\text { associated with a more } \\
\text { favorable response }\end{array}$ \\
\hline $\begin{array}{l}\text { Farooque M et al., } \\
\quad 2017 \text { [56] }\end{array}$ & Case series & $\begin{array}{l}10 \text { mg dexamethasone }(1 \mathrm{~mL}) \\
+ \text { an equal volume of } 2 \% \\
\text { preservative-free lidocaine on } \\
\text { each side (transforaminal) }\end{array}$ & Baseline & $\begin{array}{c}\text { Pain score and Swiss Spinal } \\
\text { Stenosis score at baseline, 1, } 3 \text { and } \\
6 \text { months }\end{array}$ & $\begin{array}{l}\text { Reduction of } \geq 50 \% \text { in numeric pain } \\
\text { scale score in } 30 \% \text { of participants at } \\
1 \text { month, } 53 \% \text { at } 3 \text { months and } 44 \% \text { at } \\
6 \text { months. Swiss Spinal Stenosis } \\
\text { subscale scores indicated a significant } \\
\text { reduction in the proportion of } \\
\text { participants reporting the presence of } \\
\text { severe pain in the back, buttocks and } \\
\text { legs during FU compared to baseline } \\
\qquad(p<0.05)\end{array}$ \\
\hline $\begin{array}{l}\text { Hammerich A et al., } \\
2019[57]\end{array}$ & $\begin{array}{c}\text { Randomized } \\
\text { parallel-group trial }\end{array}$ & $\begin{array}{l}1.5 \mathrm{~mL} \text { steroid (not specified) } \\
\text { at each site injected. Reassess } \\
\text { at } 3-4 \text { and } 6-8 \text { weeks for } \\
\text { potential second and } \\
\text { third injections }\end{array}$ & $\begin{array}{l}1.5 \mathrm{~mL} \text { of steroid (not } \\
\text { specified) at each site injected. } \\
\text { Reassess at } 3-4 \text { and } \\
6-8 \text { weeks for potential } \\
\text { second and third injections + } \\
\text { physical therapy (PT) }\end{array}$ & $\begin{array}{l}\text { Disability, pain, quality of life and } \\
\text { global rating of change were } \\
\text { collected at } 10 \text { weeks, } 6 \text { months } \\
\text { and } 1 \text { year, and then analyzed } \\
\text { using linear mixed model analysis }\end{array}$ & $\begin{array}{l}\text { The ESI plus PT was not superior to } \\
\text { ESI alone for reducing disability in } \\
\text { individuals with LSS. }\end{array}$ \\
\hline
\end{tabular}


Table 2. Cont.

\begin{tabular}{|c|c|c|c|c|c|}
\hline \multirow[t]{2}{*}{ Authors, Year } & \multirow[t]{2}{*}{ Study Design } & \multicolumn{2}{|c|}{ Study Protocol } & \multirow[t]{2}{*}{ Outcome Measures } & \multirow[t]{2}{*}{ Summary of Findings } \\
\hline & & Intervention & Control & & \\
\hline $\begin{array}{l}\text { Brown LL et al., } \\
\quad 2012 \text { [58] }\end{array}$ & $\begin{array}{l}\text { Randomized } \\
\text { controlled trial }\end{array}$ & $\begin{array}{l}80 \mathrm{mg} \text { triamcinolone acetate } \\
\text { (40 mg for diabetic patients) } \\
\text { mixed with } 6 \mathrm{~mL} \\
\text { preservative-free saline } \\
\text { injected in divided doses at } \\
\text { the treated levels }\end{array}$ & $\begin{array}{l}\text { MILD procedure: a } \\
\text { minimally invasive posterior } \\
\text { lumbar decompression } \\
\text { performed fluoroscopically } \\
\text { through a small 6-gauge port }\end{array}$ & $\begin{array}{l}\text { Visual Analog Scale, Oswestry } \\
\text { Disability Index and Zurich } \\
\text { Claudication Questionnaire (ZCQ) } \\
\text { for patient satisfaction }\end{array}$ & $\begin{array}{l}\text { MILD procedure was superior } \\
\text { compared to ESI in pain reduction and } \\
\text { the improvement of } \\
\text { functional mobility }\end{array}$ \\
\hline $\begin{array}{l}\text { Kim HJ et al., } \\
2013 \text { [62] }\end{array}$ & $\begin{array}{l}\text { Prospective, } \\
\text { single arm }\end{array}$ & $\begin{array}{l}40 \mathrm{mg}(1 \mathrm{~mL}) \text { triamcinolone } \\
\text { acetonide suspension }+1 \mathrm{~mL} \\
\text { bupivacaine hydrochloride } \\
0.5 \%+1 \mathrm{~mL} \text { of saline }\end{array}$ & Baseline & $\begin{array}{l}\text { Pain sensitivity questionnaire } \\
\text { (PSQ), Oswestry Disability Index } \\
\text { (ODI), and Visual Analog Scale } \\
\text { (VAS) for back and leg pain }\end{array}$ & $\begin{array}{l}\text { Significant decreases in VAS for } \\
\text { back/leg pain and ODI } 2 \text { months after } \\
\text { ESI. Individual pain sensitivity does } \\
\text { not influence the outcomes of ESI } \\
\text { treatment in patients with LSS }\end{array}$ \\
\hline $\begin{array}{l}\text { Campbell MJ et al., } \\
2007 \text { [60] }\end{array}$ & $\begin{array}{l}\text { Controlled clinical } \\
\text { trial }\end{array}$ & $\begin{array}{l}\text { Steroids (not specified) once a } \\
\text { week for } 3 \text { weeks }\end{array}$ & Baseline & $\begin{array}{l}\text { Spinal canal dimension, resolution } \\
\text { of symptoms after ESI, necessity of } \\
\text { surgery after ESI }\end{array}$ & $\begin{array}{l}\text { Spinal canal dimension is not } \\
\text { predictive of the success or failure of } \\
\text { ESIs in patients with LSS }\end{array}$ \\
\hline $\begin{array}{l}\text { Milburn J et al., } \\
2014 \text { [63] }\end{array}$ & $\begin{array}{l}\text { Randomized } \\
\text { controlled trial }\end{array}$ & $\begin{array}{l}2 \mathrm{~mL} 40 \mathrm{mg} / \mathrm{mL} \\
\text { methylprednisolone }+2 \mathrm{~mL} \\
\text { bupivacaine } 0.25 \%+2 \mathrm{~mL} \\
\text { normal saline at the most } \\
\text { stenotic level }\end{array}$ & $\begin{array}{c}2 \mathrm{~mL} 40 \mathrm{mg} / \mathrm{mL} \\
\text { methylprednisolone }+2 \mathrm{~mL} \\
\text { bupivacaine } 0.25 \%+2 \mathrm{~mL} \\
\text { normal saline at } 2 \\
\text { intervertebral levels cephalad } \\
\text { of the level of } \\
\text { maximal stenosis }\end{array}$ & $\begin{array}{l}\text { Analog pain scale from } 0 \text { to } 10 \\
\text { during ambulation and at rest, } \\
\text { Roland-Morris Disability } \\
\text { Questionnaire (RDQ) at baseline, } \\
\text { immediately after ESI and at } 1,4, \\
\text { and } 12 \text { weeks post-injection }\end{array}$ & $\begin{array}{l}\text { Symptom improvement is optimized } \\
\text { when the ESI is performed at the } \\
\text { intervertebral level of maximal stenosis }\end{array}$ \\
\hline $\begin{array}{l}\text { Bajpai S et al., } \\
2020[64]\end{array}$ & $\begin{array}{l}\text { Randomized } \\
\text { controlled trial }\end{array}$ & $\begin{array}{l}5 \mathrm{~mL} \text { bupivacaine }(0.25 \%)+ \\
2 \mathrm{~mL} \text { methylprednisolone } \\
\text { acetate }(40 \mathrm{mg} / \mathrm{mL})+1 \mathrm{~mL} \\
\text { normal saline at maximal } \\
\text { stenotic intervertebral level }\end{array}$ & $\begin{array}{c}5 \mathrm{~mL} \text { bupivacaine }(0.25 \%)+ \\
2 \mathrm{~mL} \text { methylprednisolone } \\
\text { acetate }(40 \mathrm{mg} / \mathrm{mL})+1 \mathrm{~mL} \\
\text { normal saline } 2 \text { intervertebral } \\
\text { levels cephalad to the level of } \\
\text { maximal stenosis }\end{array}$ & $\begin{array}{c}\text { Numeric Pain Rating Scale (NPRS) } \\
\text { and Oswestry Disability Index } \\
\text { (ODI) at 2, } 6 \text { and } 12 \text { weeks after } \\
\text { the intervention }\end{array}$ & $\begin{array}{l}\text { Pain relief improvement is optimized } \\
\text { when the ESI is performed at the } \\
\text { maximum stenotic intervertebral level }\end{array}$ \\
\hline
\end{tabular}


Table 2. Cont.

\begin{tabular}{|c|c|c|c|c|c|}
\hline \multirow[t]{2}{*}{ Authors, Year } & \multirow[t]{2}{*}{ Study Design } & \multicolumn{2}{|c|}{ Study Protocol } & \multirow[t]{2}{*}{ Outcome Measures } & \multirow[t]{2}{*}{ Summary of Findings } \\
\hline & & Intervention & Control & & \\
\hline $\begin{array}{l}\text { Koc Z et al., } \\
2009 \text { [59] }\end{array}$ & $\begin{array}{l}\text { Randomized } \\
\text { controlled trial }\end{array}$ & $\begin{array}{l}\text { Group 1: inpatient physical } \\
\text { therapy program for } 2 \text { weeks } \\
\text { Group 2: } 60 \mathrm{mg} \\
\text { triamcinolone acetonide }+ \\
15 \mathrm{mg} 0.5 \% \text { bupivacaine } \\
\text { hydrochloride }+5.5 \mathrm{~mL} \text { saline }\end{array}$ & Group 3: no intervention & $\begin{array}{l}\text { Pain severity by Visual Analog } \\
\text { Scale (VAS), Finger Floor Distance } \\
\text { (FFD) (cm), Treadmill Walk Test, } \\
\text { Sit-to-Stand } \\
\text { Test (Seconds), Weight-Carrying } \\
\text { (WC) Test (Seconds) }\end{array}$ & $\begin{array}{l}\text { Both ESI and physical therapy groups } \\
\text { demonstrated an improvement in } \\
\text { symptoms and in outcomes measured } \\
\text { without any significant differences }\end{array}$ \\
\hline $\begin{array}{l}\text { Manchikanti L et al., } \\
2015 \text { [65] }\end{array}$ & $\begin{array}{l}\text { Randomized } \\
\text { controlled trial }\end{array}$ & $\begin{array}{l}\text { Local anesthetic (lidocaine } \\
0.5 \%) 5 \mathrm{~mL} \text { mixed }+6 \mathrm{mg} \\
\text { betamethasone }(1 \mathrm{~mL})\end{array}$ & $\begin{array}{l}6 \mathrm{~mL} \text { local anesthetic } \\
\text { (lidocaine } 0.5 \% \text { ) }\end{array}$ & $\begin{array}{l}\text { Numeric Pain Rating Rcale (NPRS) } \\
\text { and Oswestry Disability Index } \\
\text { (ODI) at } 3,6,12,18 \text { and } 24 \text { months } \\
\text { post-treatment }\end{array}$ & $\begin{array}{c}\text { Epidural injections of local anesthetic } \\
\text { with or without steroids provide relief } \\
\text { in a significant proportion of patients } \\
\text { with LSS }\end{array}$ \\
\hline $\begin{array}{l}\text { Shamov T et al., } \\
2020 \text { [61] }\end{array}$ & Prospective, two arms & $\begin{array}{r}\text { Group 1: } 10 \mathrm{mg} \text { dexamethason } \\
\text { patients with di } \\
\text { Group2: } 10 \mathrm{mg} \text { dexamethason } \\
\text { patients }\end{array}$ & $\begin{array}{l}\text { n } 3 \text { cc } 0.25 \% \text { bupivacaine for } \\
\text { genic sciatica } \\
\text { n } 3 \text { cc } 0.25 \% \text { bupivacaine for } \\
\text { th LSS }\end{array}$ & $\begin{array}{l}\text { Pain intensity was assessed by VAS } \\
\text { at baseline and on days } 1,15 \text { and } \\
30 \text { after intervention }\end{array}$ & $\begin{array}{c}\text { ESIs are more effective in patients with } \\
\text { discogenic sciatica than in single level } \\
\text { LSS. In multiple level LSS, results are } \\
\text { disappointing }\end{array}$ \\
\hline $\begin{array}{l}\text { Friedly JL et al., } \\
\quad 2014 \text { [66] }\end{array}$ & $\begin{array}{l}\text { Randomized } \\
\text { controlled trial }\end{array}$ & $\begin{array}{c}1 \text { to } 3 \mathrm{~mL} 0.25 \% \text { to } 1 \% \\
\text { lidocaine followed by } 1 \text { to } \\
3 \mathrm{~mL} \text { triamcinolone ( } 60 \text { to } \\
120 \mathrm{mg} \text { ), betamethasone ( } 6 \text { to } \\
12 \mathrm{mg} \text { ), dexamethasone ( } 8 \text { to } \\
10 \mathrm{mg} \text { ) or } \\
\text { methylprednisolone ( } 60 \text { to } \\
120 \mathrm{mg} \text { ) }\end{array}$ & $\begin{array}{l}1 \text { to } 3 \mathrm{~mL} 0.25 \% \text { to } 1 \% \\
\text { lidocaine alone }\end{array}$ & $\begin{array}{l}\text { Roland-Morris Disability } \\
\text { Questionnaire (RDQ) and the } \\
\text { rating of leg pain intensity (on a } \\
\text { scale from } 0 \text { to } 10 \text { ) at } 6 \text { weeks } \\
\text { after injection }\end{array}$ & $\begin{array}{l}\text { Epidural injections of glucocorticoids } \\
\text { plus lidocaine offered minimal or no } \\
\text { short-term benefits compared to } \\
\text { epidural injections of lidocaine alone }\end{array}$ \\
\hline $\begin{array}{l}\text { Makris UE et al., } \\
2017 \text { [66] }\end{array}$ & $\begin{array}{l}\text { Subsequent analysis } \\
\text { of a randomized } \\
\text { controlled trial } \\
\text { (Friedly JL et al., } \\
2014 \text { [58]) }\end{array}$ & $\begin{array}{c}1 \text { to } 3 \mathrm{~mL} 0.25 \% \text { to } 1 \% \\
\text { lidocaine followed by } 1 \text { to } \\
3 \mathrm{~mL} \text { triamcinolone ( } 60 \text { to } \\
120 \mathrm{mg} \text { ), betamethasone ( } 6 \text { to } \\
12 \mathrm{mg} \text { ), dexamethasone ( } 8 \text { to } \\
10 \mathrm{mg} \text { ) or } \\
\text { methylprednisolone ( } 60 \text { to } \\
120 \mathrm{mg} \text { ) }\end{array}$ & $\begin{array}{l}1 \text { to } 3 \mathrm{~mL} 0.25 \% \text { to } 1 \% \\
\text { lidocaine alone }\end{array}$ & $\begin{array}{c}\text { RDQ (Roland-Morris Disability } \\
\text { Questionnaire), Sickness Impact } \\
\text { Profile (SIP) weights assigned to } \\
\text { the RDQ items and } \\
\text { patient-prioritized RDQ items at } \\
6 \text { weeks after injection }\end{array}$ & $\begin{array}{l}\text { No significant difference between } \\
\text { groups for the RDQ or } \\
\text { patient-prioritized RDQ, and while the } \\
\text { difference between groups for RDQ } \\
\text { using SIP weights was statistically } \\
\text { significant, this was not } \\
\text { clinically important }\end{array}$ \\
\hline
\end{tabular}


Table 2. Cont.

\begin{tabular}{|c|c|c|c|c|c|}
\hline \multirow[t]{2}{*}{ Authors, Year } & \multirow[t]{2}{*}{ Study Design } & \multicolumn{2}{|c|}{ Study Protocol } & \multirow[t]{2}{*}{ Outcome Measures } & \multirow[t]{2}{*}{ Summary of Findings } \\
\hline & & Intervention & Control & & \\
\hline $\begin{array}{c}\text { Tomkins-Lane CC } \\
\text { et al., } \\
2012 \text { [68] }\end{array}$ & $\begin{array}{l}\text { Prospective, } \\
\text { single arm }\end{array}$ & Steroids, not specified & Baseline & $\begin{array}{c}\text { Total activity (performance) } \\
\text { measured over } 7 \text { days and } \\
\text { maximum continuous activity } \\
\text { (capacity), walking capacity was } \\
\text { also assessed with the Self-Paced } \\
\text { Walking Test and subjects } \\
\text { completed the ODI, SSSQ, Medical } \\
\text { Outcomes Study 36-Item } \\
\text { Short-Form Health Survey, Visual } \\
\text { Analog Pain scales and } \\
\text { body diagrams }\end{array}$ & $\begin{array}{l}\text { At } 1 \text { week postinjection, } 58.8 \% \text { of the } \\
\text { subjects demonstrated increased total } \\
\text { activity and } 53 \% \text { had increased } \\
\text { maximum continuous activity, } \\
\text { although neither change was } \\
\text { statistically significant. } \\
\text { Patients perceived improvements in } \\
\text { symptoms, but these were not reflected } \\
\text { in significant changes in performance } \\
\text { or capacity }\end{array}$ \\
\hline $\begin{array}{l}\text { Rivest C et al., } \\
1998 \text { [69] }\end{array}$ & Prospective, two arms & $\begin{array}{r}\text { Group 1: } 3 \mathrm{~mL} 0.5 \% \text { lidoca } \\
\text { acetate, followed by } 3 \mathrm{r} \\
\text { Group 2: } 3 \mathrm{~mL} 0.5 \% \text { lidoca } \\
\text { acetate, followed by } \\
\text { disco }\end{array}$ & $\begin{array}{l}3 \mathrm{~mL} \text { methylprednisolone } \\
\text { e for patients with LSS } \\
3 \mathrm{~mL} \text { methylprednisolone } \\
\text { ine for patients with } \\
\text { atica }\end{array}$ & $\begin{array}{l}\text { Pain was assessed at baseline and } \\
2 \text { weeks following a single ESI } \\
\text { using a Visual Analog Scale }\end{array}$ & $\begin{array}{l}\text { LSS patients have worse responses to } \\
\text { ESIs than herniated disk patients }\end{array}$ \\
\hline
\end{tabular}

ESI = epidural steroid injection; LSS = lumbar spinal stenosis; LA = local anesthetic; FU = follow-up; VAS = Visual Analog Scale; ODI = Oswestry Disability Index; SSSQ = Swiss Spina Stenosis Questionnaire; SMWT = 6-Minute Walk Test; $\mathrm{MRI}=$ magnetic resonance imaging; $\mathrm{PT}=$ physical therapy; $\mathrm{MILD}=$ minimally invasive lumbar decompression; $\mathrm{ZCQ}=\mathrm{Zurich}$ Claudication Questionnaire; PSQ = Pain Sensitivity Questionnaire; FFD = Finger Floor Distance; SIP = Sickness Impact Profile. 


\subsection{Image-Guided Epidural Injections}

Special consideration should be given to image-guided techniques that may help the clinician in performing epidural injections, although no significant difference has been shown regarding outcomes. The use of ultrasound in performing an interlaminar approach could help to estimate the distance from the skin to the epidural space and the optimal needle direction $[73,74]$. However, although it is a radiation-free technique, ultrasound is limited by the operator's experience and the real-time visualization of needle tip advancement could be challenging, especially in obese patients [75]. Fluoroscopy (x-rays) and computerized tomography (CT) have both proved to be effective and safe techniques for guiding transforaminal epidural injections, although the former provides less radiation exposure for patients [76,77]. Moreover, new generation CT devices may integrate neuronavigation systems that are able to perform a computerized analysis in order to best define the needle's path towards the epidural space. Its use has been described for spinal surgery but it may be expanded to transforaminal epidural injections as well, although the high cost of these devices should be considered [78]. Future studies are expected to determine the best technique in terms of efficacy and safety for both patients and clinicians.

\section{Discussion}

Chronic lumbar pain is a widespread problem, which affects a large part of population at some point of their life. Disk herniation and canal stenosis are the most common causes and they need to be treated due to the high impact of the symptoms on patients' quality of life, especially because they could affect walking and ability to work [18].

Surgical intervention has been proven to be effective but is not usually considered as the first option [7]. On the other hand, nonsurgical treatments, such as epidural steroid injections, do not have clear literature consensus. Fully understanding whether ESIs would be able to relieve symptoms and delay or prevent surgery could be a crucial step, especially because chronic back pain patients are typically elderly and multimorbid who could be more affected by the impact of surgery.

In this narrative review, we tried to analyze the existing literature regarding the use ESIs for these kinds of patients, considering randomized controlled studies as well as reviews, meta-analyses and guidelines.

Overall, ESIs seem to be safe and quite effective in relieving the main symptoms, especially in short-term follow-ups, and in delaying surgery, according to a consistent number of studies and to the guideline written by Kreiner and colleagues [52]. Moreover, ESIs could be more powerful in the case of patients with disk herniation than patients with canal stenosis [61]. Attention should also be paid to the technique and to the vertebral level of the injection, at least for spinal stenosis $[63,64]$.

As mentioned before, literature consensus is still missing and numerous studies did not find significative improvements, especially in long-term follow-ups. In addition, it seems to be difficult to find significative differences between using local anesthetics alone or local anesthetics plus steroids in the injection.

Due to the anti-inflammatory action of steroids, patients with high local inflammatory status could probably benefit more from using steroids [49]. However, epidural steroid injections have also been associated with potential adverse effects, including acute neurological symptoms $[79,80]$, in addition to other possible complications related to the epidural technique, i.e., inadvertent dural puncture, hematomas and infection. [81]

In this context, the identity of the patients who could benefit the most from this procedure has not been completely established yet and could be a crucial future goal.

This narrative review has some limitations. Firstly, the studies taken into consideration did have different epidural injection approaches. Secondly, the heterogeneity of the enrolled patients, analyzed parameters and data collection in the studies taken into consideration could be an important bias. Lastly, the heterogeneity of the purposes of the studies, such 
as the comparison of steroid injections versus nothing or local anesthetic injections versus local anesthetic plus steroids, could make global analysis difficult.

Surely, more randomized studies with larger numbers of patients are needed to fully understand the efficacy of ESIs and define which patients could benefit more from the procedure, especially in order to delay or prevent surgery.

\section{Conclusions}

According to the literature analyzed in this narrative review, there is no consensus on the use of ESIs for patients with chronic lumbar pain. ESIs seem to be effective in relieving symptoms in the short term and delaying surgery, while evidence of any long-terms benefits is still lacking. More studies are needed to better understand which patients could benefit more from epidural steroid injections.

Author Contributions: Conceptualization, M.C. and G.P.; methodology, G.F.P. and M.P.; software, C.M.; validation, A.S., G.P. and M.C.; formal analysis, F.D.T.; investigation, A.S. and E.S.; resources, R.C.; data curation, F.R.; writing-original draft preparation, A.S.; writing-review and editing, F.C. and G.F.P.; visualization, F.G. and F.R.; supervision, M.C.; project administration, F.E.A. All authors have read and agreed to the published version of the manuscript.

Funding: This research received no external funding.

Institutional Review Board Statement: Not applicable.

Informed Consent Statement: Not applicable.

Data Availability Statement: Not applicable.

Conflicts of Interest: The authors declare no conflict of interest.

\section{References}

1. Dieleman, J.L.; Cao, J.; Chapin, A.; Chen, C.; Li, Z.; Liu, A.; Horst, C.; Kaldjian, A.; Matyasz, T.; Scott, K.; et al. US Health Care Spending by Payer and Health Condition, 1996-2016. JAMA 2020, 323, 863-884. [CrossRef]

2. Mokdad, A.H.; Ballestros, K.; Echko, M.; Glenn, S.; Olsen, H.E.; Mullany, E.; Lee, A.; Khan, A.R.; Ahmadi, A.; Ferrari, A.J.; et al. The State of US Health, 1990-2016: Burden of Diseases, Injuries, and Risk Factors Among US States. JAMA 2018, 319, $1444-1472$. [PubMed]

3. Kennedy, D.; Plastaras, C.; Casey, E.; Visco, C.J.; Rittenberg, J.; Conrad, B.; Sigler, J.; Dreyfuss, P. Comparative Effectiveness of Lumbar Transforaminal Epidural Steroid Injections with Particulate Versus Nonparticulate Corticosteroids for Lumbar Radicular Pain due to Intervertebral Disc Herniation: A Prospective, Randomized, Double-Blind Trial. Pain Med. 2014, 15, 548-555. [CrossRef] [PubMed]

4. $\quad$ Spijker-Huiges, A.; Winters, J.C.; Van Wijhe, M.; Groenier, K. Steroid injections added to the usual treatment of lumbar radicular syndrome: A pragmatic randomized controlled trial in general practice. BMC Musculoskelet. Disord. 2014, 15, 341. [CrossRef]

5. Zhai, J.; Zhang, L.; Li, M.; Tian, Y.; Zheng, W.; Chen, J.; Huang, T.; Li, X.; Tian, Z. Epidural injection with or without steroid in managing chronic low back and lower extremity pain: Ameta-analysis of ten randomized controlled trials. Int. J. Clin. Exp. Med. 2015, 8, 8304-8316. [CrossRef] [PubMed]

6. $\quad$ Lee, J.; Shin, J.-S.; Lee, Y.J.; Kim, M.-R.; Ahn, Y.-J.; Park, K.B.; Kropf, M.A.; Shin, B.-C.; Lee, M.S.; Ha, I.-H. Effects of Shinbaro pharmacopuncture in sciatic pain patients with lumbar disc herniation: Study protocol for a randomized controlled trial. Trials 2015, 16, 455. [CrossRef]

7. Chen, B.-L.; Guo, J.-B.; Zhang, H.-W.; Zhang, Y.-J.; Zhu, Y.; Zhang, J.; Hu, H.-Y.; Zheng, Y.-L.; Wang, X.-Q. Surgical versus non-operative treatment for lumbar disc herniation: A systematic review and meta-analysis. Clin. Rehabilit. 2018, 32, 146-160. [CrossRef]

8. Carassiti, M.; Di Martino, A.; Centonze, A.; Quattrocchi, C.C.; Caldaria, A.; Agrò, F.; Denaro, V. Failed back surgery syndrome: A new strategy by the epidural injection of MESNA. Musculoskelet. Surg. 2018, 102, 179-184. [CrossRef]

9. Kozlov, N.; Benzon, H.T.; Malik, K.M. Epidural steroid injections: Update on efficacy, safety, and newer medications for injection. Minerva Anestesiol. 2015, 81, 901-909.

10. Carassiti, M.; Cataldo, R.; Formica, D.; Massaroni, C.; De Filippis, A.; Palermo, P.; Di Tocco, J.; Setola, R.; Valenti, C.; Schena, E. A new pressure guided management tool for epidural space detection: Feasibility assessment in a clinical scenario. Minerva Anestesiol. 2020, 86, 736-741. [CrossRef] [PubMed]

11. Carassiti, M.; Mattei, A.; Quarta, R.; Massaroni, C.; Saccomandi, P.; Tesei, M.; Setola, R.; Schena, E. A New Pressure Guided Management Tool for Epidural Space Detection: Feasibility Assessment on a Simulator. Artif. Organs 2017, 41, E320-E325. [CrossRef] 
12. Tesei, M.; Saccomandi, P.; Massaroni, C.; Quarta, R.; Carassiti, M.; Schena, E.; Setola, R. A cost-effective, non-invasive system for pressure monitoring during epidural needle insertion: Design, development and bench tests. In Proceedings of the 2016 38th Annual International Conference of the IEEE Engineering in Medicine and Biology Society (EMBC), Orlando, FL, USA, 16-20 August 2016; pp. 194-197.

13. Carassiti, M.; Quarta, R.; Mattei, A.; Tesei, M.; Saccomandi, P.; Massaroni, C.; Setola, R.; Schena, E. Ex vivo animal-model assessment of a non-invasive system for loss of resistance detection during epidural blockade. In Proceedings of the 2017 39th Annual International Conference of the IEEE Engineering in Medicine and Biology Society (EMBC), Jeju, Korea, 11-15 July 2017; pp. 759-762.

14. Carassiti, M.; Pascarella, G.; Strumia, A.; Cataldo, R.; Antinolfi, V.; Costa, F.; Agrò, F.E. Pressure monitoring devices may undetect epidural space: A report on the use of Compuflo®system for epidural injection. J. Clin. Monit. 2021. [CrossRef]

15. de Tommasi, F.; Lo Presti, D.; Virgili, F.; Massaroni, C.; Schena, E.; Carassiti, M. Soft System Based on Fiber Bragg Grating Sensor for Loss of Resistance Detection during Epidural Procedures: In Silico and In Vivo Assessment. Sensors 2021, 21, 5329. [CrossRef] [PubMed]

16. de Tommasi, F.; Presti, D.L.; Massaroni, C.; Schena, E.; Carassiti, M. FBG-based System for Loss of Resistance Detection During Epidural Injections. In Proceedings of the 2021 IEEE International Workshop on Metrology for Industry 4.0 \& IoT (MetroInd4. 0\&IoT), Rome, Italy, 7-9 June 2021; IEEE: Rome, Italy, 2021; pp. 172-176.

17. Huang, W.; Han, Z.; Liu, J.; Yu, L.; Yu, X. Risk Factors for Recurrent Lumbar Disc Herniation: A Systematic Review and Meta-Analysis. Medicine 2016, 95, e2378. [CrossRef] [PubMed]

18. Wheeler, A.H.; Murrey, D.B. Chronic lumbar spine and radicular pain: Pathophysiology and treatment. Curr. Pain Headache Rep. 2002, 6, 97-105. [CrossRef] [PubMed]

19. McCarron, R.F.; Wimpee, M.W.; Hudkins, P.G.; Laros, G.S. The inflammatory effect of nucleus pulposus. A possible element in the pathogenesis of low-back pain. Spine 1987, 12, 760-764. [CrossRef]

20. Deyo, R.A.; Mirza, S.K. Clinical Practice. Herniated Lumbar Intervertebral Disk. N. Engl. J. Med. 2016, 374, 1763-1772. [CrossRef]

21. Deer, T.; Sayed, D.; Michels, J.; Josephson, Y.; Li, S.; Calodney, A.K. A Review of Lumbar Spinal Stenosis with Intermittent Neurogenic Claudication: Disease and Diagnosis. Pain Med. 2019, 20, S32-S44. [CrossRef]

22. Coutinho, A.E.; Chapman, K.E. The anti-inflammatory and immunosuppressive effects of glucocorticoids, recent developments and mechanistic insights. Mol. Cell. Endocrinol. 2011, 335, 2-13. [CrossRef]

23. Manchikanti, L.; Knezevic, N.N.; Parr, A.; Kaye, A.D.; Sanapati, M.; Hirsch, J.A. Does Epidural Bupivacaine with or Without Steroids Provide Long-Term Relief? A Systematic Review and Meta-analysis. Curr. Pain Headache Rep. 2020, 24, 26. [CrossRef]

24. Bogduk, N. Epidural steroids. Spine 1995, 20, 845-848. [CrossRef] [PubMed]

25. Yasir, M.; Goyal, A.; Bansal, P.; Sonthalia, S. Corticosteroid Adverse Effects. In StatPearls; StatPearls Publishing: Treasure Island, FL, USA, 2021.

26. Yang, S.; Kim, W.; Kong, H.H.; Do, K.H.; Choi, K.H. Epidural steroid injection versus conservative treatment for patients with lumbosacral radicular pain: A meta-analysis of randomized controlled trials. Medicine 2020, 99, e21283. [CrossRef] [PubMed]

27. Knezevic, N.N.; Manchikanti, L.; Urits, I.; Orhurhu, V.; Vangala, B.P.; Vanaparthy, R.; Sanapati, M.R.; Shah, S.; Soin, A.; Mahajan, A.; et al. Lack of Superiority of Epidural Injections with Lidocaine with Steroids Compared to Without Steroids in Spinal Pain: A Systematic Review and Meta-Analysis. Pain Physician 2020, 23, 239.

28. Zhao, W.; Wang, Y.; Wu, J.; Gao, X.; Wei, Q.; Lai, X.; An, J. Long-Term Outcomes of Epidurals with Lidocaine With or Without Steroids for Lumbar Disc Herniation and Spinal Stenosis: A Meta-Analysis. Pain Physician 2020, 23, 365-374.

29. Manchikanti, L.; Soin, A.; Mann, D.P.; Bakshi, S.; Pampati, V.; Hirsch, J.A. Comparative Analysis of Utilization of Epidural Procedures in Managing Chronic Pain in the Medicare Population: Pre and Post Affordable Care Act. Spine 2019, 44, $220-232$. [CrossRef] [PubMed]

30. Manchikanti, L.; Sanapati, M.R.; Pampati, V.; Soin, A.; Atluri, S.; Kaye, A.D.; Subramanian, J.; Hirsch, J.A. Update of Utilization Patterns of Facet Joint Interventions in Managing Spinal Pain from 2000 to 2018 in the US Fee-for-Service Medicare Population. Pain Physician 2020, 23, E133-E149. [CrossRef]

31. Manchikanti, L.; Gharibo, C.G.; Gilligan, C.J.; Hirsch, J.A.; Nampiaparampil, D.E.; Manchikanti, K.N.; Falco, F.E.; Singh, V.; Benyamin, R.M.; Kaye, A.D.; et al. Comparison of the efficacy of saline, local anesthetics, and steroids in epidural and facet joint injections for the management of spinal pain: A systematic review of randomized controlled trials. Surg. Neurol. Int. 2015, 6, 194-235. [CrossRef] [PubMed]

32. Lundin, A.; Magnuson, A.; Axelsson, K.; Nilsson, O.; Samuelsson, L. Corticosteroids Peroperatively Diminishes Damage to the C-Fibers in Microscopic Lumbar Disc Surgery. Spine 2005, 30, 2362-2367. [CrossRef]

33. Hayashi, N.; Weinstein, J.N.; Meller, S.T.; Lee, H.-M.; Spratt, K.F.; Gebhart, G.F. The Effect of Epidural Injection of Betamethasone or Bupivacaine in a Rat Model of Lumbar Radiculopathy. Spine 1998, 23, 877-885. [CrossRef]

34. Johansson, A.; Hao, J.; Sjölund, B. Local corticosteroid application blocks transmission in normal nociceptive C-fibres. Acta Anaesthesiol. Scand. 1990, 34, 335-338. [CrossRef]

35. Wong, S.H.; Wong, C.S.; Li, T.T. Steroids in regional analgesia. Expert Opin. Pharmacother. 2010, 11, 2839-2848. [CrossRef] [PubMed] 
36. Shanthanna, H.; Busse, J.W.; Thabane, L.; Paul, J.; Couban, R.; Choudhary, H.; Kaushal, A.; Suzumura, E.; Kim, I.; Harsha, P. Local anesthetic injections with or without steroid for chronic non-cancer pain: A protocol for a systematic review and meta-analysis of randomized controlled trials. Syst. Rev. 2016, 5, 18. [CrossRef] [PubMed]

37. Manchikanti, L.; Cash, K.A.; Pampati, V.; Falco, F.J.E. Transforaminal epidural injections in chronic lumbar disc herniation: A randomized, double-blind, active-control trial. Pain Physician 2014, 17, 489-501. [CrossRef]

38. Manchikanti, L.; Singh, V.; Cash, K.A.; Pampati, V.; Falco, F.J.E. A randomized, double-blind, active-control trial of the effectiveness of lumbar interlaminar epidural injections in disc herniation. Pain Physician 2014, 17, 61-74. [CrossRef]

39. Lee, J.H.; Shin, K.-H.; Park, S.J.; Lee, G.J.; Lee, C.-H.; Kim, D.H.; Kim, D.H.; Yang, H.S. Comparison of Clinical Efficacy Between Transforaminal and Interlaminar Epidural Injections in Lumbosacral Disc Herniation: A Systematic Review and Meta-Analysis. Pain Physician 2018, 21, 433-448. [CrossRef]

40. Sariyildiz, M.A.; Batmaz, I.; Yazmalar, L.; Güneş, M.; Turan, Y. The effectiveness of transforaminal epidural steroid injections on radicular pain, functionality, psychological status and sleep quality in patients with lumbar disc herniation. J. Back Musculoskelet. Rehabilitation 2017, 30, 265-270. [CrossRef]

41. Guclu, B.; Deniz, L.; Yuce, Y.; Adilay, U.; Aytar, H.; Turkoglu, M.; Tiryaki, M.; Ozdek, R.; Boran, B.O. Transforaminal Epidural Steroid Injection in the Treatment of Pain in Foraminal and Paramedian Lumbar Disc Herniations. Turk. Neurosurg. 2020, 30, 394-399. [CrossRef]

42. Manchikanti, L.; Singh, V.; Cash, K.A.; Pampati, V.; Falco, F.J.E. The Role of Fluoroscopic Interlaminar Epidural Injections in Managing Chronic Pain of Lumbar Disc Herniation or Radiculitis: A Randomized, Double-Blind Trial. Pain Pract. 2012, 13, 547-558. [CrossRef]

43. Wang, J.C.; Lin, E.; Brodke, D.S.; Youssef, J.A. Epidural Injections for the Treatment of Symptomatic Lumbar Herniated Discs. J. Spinal Disord. Tech. 2002, 15, 269-272. [CrossRef]

44. Vad, V.B.; Bhat, A.L.; Lutz, G.E.; Cammisa, F. Transforaminal epidural steroid injections in lumbosacral radiculopathy: A prospective randomized study. Spine 2002, 27, 11-16. [CrossRef] [PubMed]

45. Manchikanti, L.; Singh, V.; Cash, K.A.; Pampati, V.; Damron, K.S.; Boswell, M.V. Preliminary results of a randomized, equivalence trial of fluoroscopic caudal epidural injections in managing chronic low back pain: Part 2-Disc herniation and radiculitis. Pain Physician 2008, 11, 801-815. [CrossRef] [PubMed]

46. Kennedy, D.; Zheng, P.Z.; Smuck, M.; McCormick, Z.L.; Huynh, L.; Schneider, B.J. A minimum of 5-year follow-up after lumbar transforaminal epidural steroid injections in patients with lumbar radicular pain due to intervertebral disc herniation. Spine J. 2018, 18, 29-35. [CrossRef]

47. Buchner, M.; Zeifang, F.; Brocai, D.R.; Schiltenwolf, M. Epidural Corticosteroid Injection in the Conservative Management of Sciatica. Clin. Orthop. Relat. Res. 2000, 375, 149-156. [CrossRef] [PubMed]

48. Şencan, S.; Çelenlioğlu, A.E.; Asadov, R.; Gündüz, O.H. Predictive factors for treatment success of transforaminal epidural steroid injection in lumbar disc herniation-induced sciatica. Turk. J. Med Sci. 2020, 50, 126-131. [CrossRef]

49. Buttermann, G.R. The effect of spinal steroid injections for degenerative disc disease. Spine J. 2004, 4, 495-505. [CrossRef] [PubMed]

50. Radcliff, K.; Hilibrand, A.; Lurie, J.D.; Tosteson, T.D.; Delasotta, L.; Rihn, J.; Zhao, W.; Vaccaro, A.; Albert, T.J.; Weinstein, J.N. The impact of epidural steroid injections on the outcomes of patients treated for lumbar disc herniation: A subgroup analysis of the SPORT trial. J. Bone Jt. Surg. Am. 2012, 94, 1353-1358. [CrossRef]

51. Zhong, M.; Liu, J.-T.; Jiang, H.; Mo, W.; Yu, P.-F.; Li, X.-C.; Xue, R.R. Incidence of Spontaneous Resorption of Lumbar Disc Herniation: A Meta-Analysis. Pain Physician 2017, 20, E45-E52.

52. Kreiner, D.S.; Hwang, S.W.; Easa, J.E.; Resnick, D.K.; Baisden, J.L.; Bess, S.; Cho, C.H.; DePalma, M.J.; Dougherty, P.; Fernand, R.; et al. An evidence-based clinical guideline for the diagnosis and treatment of lumbar disc herniation with radiculopathy. Spine $J$. 2014, 14, 180-191. [CrossRef]

53. Sabbaghan, S.; Mirzamohammadi, E.; Mahabadi, M.A.; Nikouei, F.; Rahbarian, F.; Ahmadichaboki, S.; Eftekhari, S.; Zamankhani, M.; Aghdam, A.A. Short-Term Efficacy of Epidural Injection of Triamcinolone Through Translaminar Approach for the Treatment of Lumbar Canal Stenosis. Anesthesiol. Pain Med. 2020, 10, e99764. [CrossRef]

54. Park, C.-H.; Lee, S.-H. Correlation between Severity of Lumbar Spinal Stenosis and Lumbar Epidural Steroid Injection. Pain Med. 2014, 15, 556-561. [CrossRef] [PubMed]

55. Cosgrove, J.L.; Bertolet, M.; Chase, S.L.; Cosgrove, G.K. Epidural Steroid Injections in the Treatment of Lumbar Spinal Stenosis Efficacy and Predictability of Successful Response. Am. J. Phys. Med. Rehabilit. 2011, 90, 1050-1055. [CrossRef] [PubMed]

56. Farooque, M.; Salzman, M.M.; Ye, Z. Effectiveness of Bilateral Transforaminal Epidural Steroid Injections in Degenerative Lumbar Spinal Stenosis Patients With Neurogenic Claudication: A Case Series. PMER 2017, 9, 26-31. [CrossRef]

57. Hammerich, A.; Whitman, J.; Mintken, P.; Denninger, T.; Akuthota, V.; Sawyer, E.E.; Hofmann, M.; Childs, J.D.; Cleland, J. Effectiveness of Physical Therapy Combined With Epidural Steroid Injection for Individuals With Lumbar Spinal Stenosis: A Randomized Parallel-Group Trial. Arch. Phys. Med. Rehabilit. 2019, 100, 797-810. [CrossRef]

58. Brown, L.L. A Double-blind, Randomized, Prospective Study of Epidural Steroid Injection vs. The mild®Procedure in Patients with Symptomatic Lumbar Spinal Stenosis. Pain Pract. 2012, 12, 333-341. [CrossRef] [PubMed]

59. Koc, Z.; Ozcakir, S.; Sivrioglu, K.; Gurbet, A.; Kucukoglu, S. Effectiveness of Physical Therapy and Epidural Steroid Injections in Lumbar Spinal Stenosis. Spine 2009, 34, 985-989. [CrossRef] [PubMed] 
60. Campbell, M.J.; Carreon, L.Y.; Glassman, S.D.; McGinnis, M.D.; Elmlinger, B.S. Correlation of Spinal Canal Dimensions to Efficacy of Epidural Steroid Injection in Spinal Stenosis. J. Spinal Disord. Tech. 2007, 20, 168-171. [CrossRef]

61. SShamov, T.; Al-Hashel, J.Y.; Rousseff, R.T. Fluoroscopic Epidural Steroid Injection: Pain Relief in Discogenic Sciatica Versus Lumbar Spinal Stenosis. A Study on Middle Eastern Patients. Acta Med. 2020, 63, 73-78. [CrossRef]

62. Kim, H.-J.; Yeom, J.S.; Lee, J.W.; Chang, B.-S.; Lee, C.-K.; Lee, G.-W.; Im, S.-B.; Kim, H.J. The Influence of Pain Sensitivity on the Treatment Outcome of Transforaminal Epidural Steroid Injection in Patients with Lumbar Spinal Stenosis. Pain Pract. 2014, 14, 405-412. [CrossRef] [PubMed]

63. Milburn, J.; Freeman, J.; Steven, A.; Altmeyer, W.; Kay, D. Interlaminar Epidural Steroid Injection for Degenerative Lumbar Spinal Canal Stenosis: Does the Intervertebral Level of Performance Matter? Ochsner J. 2014, 14, 62-66. [PubMed]

64. Bajpai, S.; Yelavarthi, R. Effect of intervertebral level on interlaminar epidural steroid injection in lumbar spinal canal stenosis: A randomized controlled trial. Anesth. Essays Res. 2020, 14, 100-103. [CrossRef]

65. Manchikanti, L.; Cash, K.A.; McManus, C.D.; Damron, K.S.; Pampati, V.; Falco, F.J.E. A randomized, double-blind controlled trial of lumbar interlaminar epidural injections in central spinal stenosis: 2-year follow-up. Pain Physician 2015, 18, 79-92. [CrossRef] [PubMed]

66. Friedly, J.L.; Comstock, B.A.; Turner, J.A.; Heagerty, P.J.; Deyo, R.A.; Sullivan, S.D.; Bauer, Z.; Bresnahan, B.W.; Avins, A.L.; Nedeljkovic, S.S.; et al. A Randomized Trial of Epidural Glucocorticoid Injections for Spinal Stenosis. N. Engl. J. Med. 2014, 371, 11-21. [CrossRef]

67. Makris, U.E.; Edwards, T.C.; Lavallee, D.C.; Bauer, Z.; Comstock, B.A.; Jarvik, J.G.; Patrick, D.L.; Lotfi, M.; Friedly, J.L. Patient Priority Weighting of the Roland Morris Disability Questionnaire Does Not Change Results of the Lumbar Epidural Steroid Injections for Spinal Stenosis Trial. Spine 2017, 42, 42-48. [CrossRef] [PubMed]

68. Tomkins-Lane, C.C.; Conway, J.; Hepler, C.; Haig, A.J. Changes in Objectively Measured Physical Activity (Performance) after Epidural Steroid Injection for Lumbar Spinal Stenosis. Arch. Phys. Med. Rehabilit. 2012, 93, 2008-2014. [CrossRef] [PubMed]

69. Rivest, C.; Katz, J.N.; Ferrante, F.M.; Jamison, R.N. Effects of epidural steroid injection on pain due to lumbar spinal stenosis or herniated disks: A prospective study. Arthritis Care Res. 1998, 11, 291-297. [CrossRef] [PubMed]

70. Fukusaki, M.; Kobayashi, I.; Hara, T.; Sumikawa, K. Symptoms of Spinal Stenosis Do Not Improve After Epidural Steroid Injection. Clin. J. Pain 1998, 14, 148-151. [CrossRef]

71. Tran, D.Q.H.; Duong, S.; Finlayson, R.J. Lumbar spinal stenosis: A brief review of the nonsurgical management. Can. J. Anesth. 2010, 57, 694-703. [CrossRef]

72. Wu, X.; Liu, K.; Liu, P.-C.; Liu, R.; Cai, M. Steroid for epidural injection in spinal stenosis: A systematic review and meta-analysis. Drug Des. Dev. Ther. 2015, 9, 707-716. [CrossRef]

73. Hashemi, M.; Dadkhah, P.; Taheri, M.; Abootorabi, S.M.H.S.; Naderi-Nabi, B.; Haji, S.M. Ultrasound-Guided Lumbar Transforaminal Epidural Injections; A Single Center Fluoroscopic Validation Study. Bull. Emerg. Trauma 2019, 7, 251-255. [CrossRef]

74. Park, K.D.; Kim, T.K.; Lee, W.Y.; Ahn, J.; Koh, S.H.; Park, Y. Ultrasound-Guided Versus Fluoroscopy-Guided Caudal Epidural Steroid Injection for the Treatment of Unilateral Lower Lumbar Radicular Pain. Medicine 2015, 94, e2261. [CrossRef]

75. Sahin, T.; Balaban, O. Lumbar Ultrasonography for Obstetric Neuraxial Blocks: Sonoanatomy and Literature Review. Turk. J. Anesth. Reanim. 2018, 46, 257-267. [CrossRef]

76. Bui, J.; Bogduk, N. A Systematic Review of the Effectiveness of CT-Guided, Lumbar Transforaminal Injection of Steroids. Pain Med. 2013, 14, 1860-1865. [CrossRef] [PubMed]

77. Dietrich, T.J.; Peterson, C.K.; Zeimpekis, K.G.; Bensler, S.; Sutter, R.; Pfirrmann, C.W.A. Fluoroscopy-guided versus CT-guided Lumbar Steroid Injections: Comparison of Radiation Exposure and Outcomes. Radiology 2019, 290, 752-759. [CrossRef] [PubMed]

78. Tehli, O.; Harman, F.; Temiz, C.; Kacar, Y.; Kazanci, B.; Daneyemez, M.; Solmaz, I.; Kural, C. The use of neuronavigation and intraoperative imaging in spinal stabilization surgery. Turk. Neurosurg. 2016, 26, 771-776. [CrossRef]

79. Viswanath, O.; Suthar, R.; Kannan, M.; Baskin, M. Post Procedural Complication following Cervical Epidural Local Anesthetic Injection: A Case Report. Anesthesiol. Pain Med. 2017, 7, e44636. [CrossRef]

80. Field, J.; Rathmell, J.P.; Stephenson, J.H.; Katz, N.P. Neuropathic Pain following Cervical Epidural Steroid Injection. Anesthesiology 2000, 93, 885-888. [CrossRef] [PubMed]

81. Kang, X.H.; Bao, F.P.; Xiong, X.X.; Li, M.; Jin, T.T.; Shao, J.; Zhu, S.M. Major complications of epidural anesthesia: A prospective study of 5083 cases at a single hospital. Acta Anaesthesiol. Scand. 2014, 58, 858-866. [CrossRef] 